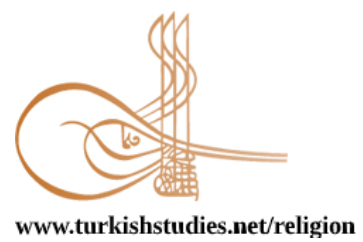

www.turkishstudies.net/religion

\section{Turkish Studies - Comparative Religious Studies}

eISSN: 2667-5544

Research Article / Araştırma Makalesi

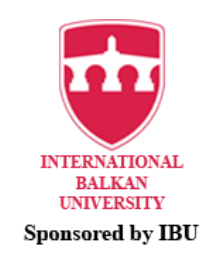

Sponsored by IBU

\title{
Yabancılaşma Olgusunun Aksiyolojik Boyutu
}

The Axiological Dimension of the Alienation Phenomenon

\author{
İbrahim Çetintaş*
}

\begin{abstract}
In this study, we dealt with the axiological dimension of the alienation phenomenon. According to this, it is understood that axiological alienation arises from the deviations or contradictions taken place between human and his historical existence. Here, the human transfers his essence to the acts he has produced, with the material or spiritual reasons, and becomes an objective element or elements by externalizing through them. With the introduction of these produced objective elements into circulation to meet the needs or desires of the external world, the existential integrity between the essence and the actions is disrupted, and the man feels alien to his externalized essence. Because, here people are respected for the sake of these acts, not because of themselves. Because what matters is not the human himself, but the external equivalent of the acts he produces. Naturally, this situation causes the human to lose his position of being a goal and becomes instrumental for someone else or other things. This situation, which starts in the acts and spreads to the whole spiritual body, leads to a decrease or develuation of human ontologically as well as axiologically. For this reason, the maintenance of the integrity between human and his historical existence is crucial. This will be possible by placing the spatial relationship/balance between the essence and acts on a right and solid ground. This will come true by accepting that human is an aim in himself, not a means for anything material or spiritual, such as religion, culture, history or tradition, including his own actions.
\end{abstract}

Structured Abstract: The quality of relationship established between the human being and the acts he produces is very important. Because the status of human's value is formed according to the way this relationship is established. In traditional Islamic thought, at least theoretically, the human actions are seen as a projection of his nature. Whatever the ontological nature of human, his axiological visibility is shaped according to it. For this reason, the personal character of human reveals with the color and shape of his acts. In this stuation, it can be made a definition or determination based on the human himself or his essence.

However, in the historical process, it is also possible to encounter scenes in which the acts are more prominent than human himself. In such cases, it is observed that the superiority of definition or determination passes from the human essence or character to his practical field. The person whose specific gravity or central position is shaken is thus weakened by these acts. In this new situation, where the spatial relationship between human and his acts changes, human becomes alien by cooling from the acts he has produced.

\footnotetext{
* Doç. Dr., Kahramanmaraş Sütçü İmam Üniversitesi, İlahiyat Fakültesi, Felsefe ve Din Bilimleri Bölümü, İslam Felsefesi Anabilim Dalı

Assoc. Prof. Dr., Sütçü İmam University, Faculty of Theology, Philosophy and Religious Studies, Department of Islamic Philosophy 
Therefore, the axiological alienation becomes real because of contradictions or deviations taken place between human and his historical existence. Because these changes that occur between essence and existence mean that the relationship between the human and his qualities or properties that he possesses is broken or deteriorated. Since the human power, opportunity or energy flows to another field outside of himself, which means the externalization of human, his integrity disrupts with the common existence.

The axiological alienation that has emerged in the course of history and the great decreases caused by this situation originate from staying the essence behind the acts, because of the disruption of human existential unity. As a result, the human is treated according to the sake of the acts he has produced rather than himself. Naturally, this situation causes the human to lose his position of being a goal and become instrumental for someone else or other things. Because the criterian of being accepted or credible in this table is based on the power of the acts produced to meet or satisfy the needs or requirements of the outside. Thus, the specific gravity of human changes from inside to outside or from essence to form. After this stage, the definition, evaluation or position of human is made according to axiological visibility rather than its essence or ontological nature. Thus, the spatial relationship between the essence or quiddity of human and his acts is disrupted, and the human being alienates himself from what he produces by his own hand

Axiological alienation can be observed both on economic or material works and on spiritual ones such as money, office, religion, morality, art, philosophy or culture. Extensive periods of history are full of examples showing how people have alienated or have being alienated by spiritual values that they have built with faith, morality or artistic works. Here, if we clarify the issue through moral acts, for example, a faithful person or more specifically any Muslim can regulate his behaviors by overcoming the egoic difficulties in order to gain the satisfaction of Allah, which can be called "beautiful morality". This behavior will emerge as a reflection of the moral essence of this person.

However, this beautiful morality built by these people with their essential qualities such as belief, emotion, thought or willpower from time to time may be abused by malevolent people. Such malecious people can easily use the spirituality of the moral owner in order to pursuade him for a blind obedience without question. The moral owner, who supposes that to give consent to his directives is the identical with the consent of God, seeks the truth value of the actions he has constructed by transferring his essence in the hope of goodness and benevolence. In this case, every act put forward by the other side is also a measure for the actions of the moral owner. Because he's behaving accorging to wishes and desires of the malecious person to which he is internally connected, and not by considering himself or his reality. Thus, the formal identity of the acts put forward belongs to the moral owner, and the determining willpower of them to the opposite side. This person, who blindly follows behind someone and surrenders to his will emerges as an alienated other or an alien who has lost his essence.

As it is here, every act arising from human soul can cause to his alienation. Although the color and nature of the acts change in this process, the phenomenon of alienation that human is exposed to through these acts produced by transferring his essence always preserves itself like a law. Moreover, beyond alienation, human can become an adversary himself through these acts. Because here the human in one way has to struggle with himself, who alineated. After these acts are objectified, they produce their own reality and form their own paradigm in front of the human harming himself from whom they originate. Because after such acts are externalized and entered into circulation, since the owner's control over them disappears, while the harm generated by these acts returns to the owner, the benefit flows to the user's household. Therefore, the phenomenon of alienation also means that man produces a self-harming enemy by his own hand.

In the ontological dimension of the alienation phenomenon, human is exposed to alienation directly from his essence, quiddity or nature, and here rather his own inner truths play role. In the axiological aspect of the issue, an indirect alienation through acts, and the external realities play role rather than internal conditons. Naturally, we can solve this problem by taking into account the external conditions that lead to this as well as the inner world of human. We can say that the specific characteristics of cultures such as the politics produced by this character or the way these fields deal with the human are among these external conditions.

Finally, we would like to emphasize that; as the conscious that dominates the behavior of the alien is formed by the codes or patterns of the outside, his conscious also will be an external conscious rather than an internal one. In the face of this new situation that starts in behavior and spreads to the mind and soul, the alien can become a completely transformed structure. For this reason, with axiological alienation, the human 
loses its divine natural texture and transforms into another structure. Therefore, the alien; even if he forms certain behaviors, these acts will not be specific, qualified acts because their main truth will be the result of someone else's mind and will. Therefore, with axiological alienation, both the practical and the essential side of human are destroyed.

Therefore, in order not to be exposed to such destructive problems, it is necessary to maintain the integrity between human and his historical existence. This will be made possible by placing the spatial relationship/balance between the essence of human and the acts on a rigt and solid foundation. The right and solid ground here means that human beings settle in their own position in the realm of being without sacrificing anything material or spiritual.

Keywords: Alienation, Human, Ontological Alienation, Axiological Alienation, Human Essence, Human Existence

Öz: Bu çalışmamızda yabancılaşma olgusunun aksiyolojik boyutunu ele aldık. Buna göre aksiyolojik yabancılaşmanın, insan ile onun tarihsel varoluşu arasındaki sapma veya çelişkilerle oluştuğu anlaşılmaktadır. Burada insan, maddî veya manevî gerekçelerle özünü, üretmiş olduğu fiillerine aktarmakta ve bunlar üzerinden dişsallaşarak, nesnel bir unsur veya unsurlara dönüşmektedir. Üretilmiş bu nesnel unsurların, dış dünyanın ihtiyaç veya arzularını karşılamak üzere dolaşıma girmesiyle birlikte öz ile fiiller arasındaki varoluşsal bütünlük bozularak insan, kendi kendinden soğumakta veya dışsallaşmış özüne karşı yabancılık hissetmektedir. Çünkü insan burada insan olduğu için değil, üretmiş olduğu bu fiillerin hatırı için itibar görmektedir. Zira önemli olan, insanın kendisi değil, üretmiş olduğu fiillerin dış dünyadaki karşılığıdır. Haliyle bu durum, insanın gaye varlık olma konumunu yitirip, başkası veya başka şeyler için araçsallaşmasına yol açmaktadır. Fiillerde başlayıp, bütün bir ruhsal bünyeye sirayet eden bu durum insanın, aksiyolojik olduğu kadar ontolojik olarak da düşüşü veya değer kaybına yol açmaktadır. Bu nedenle insan ile onun tarihsel varoluşu arasındaki bütünlüğ̈n muhafazası hayati bir öneme sahiptir. Bu ise zat ile fiiller arasındaki konumsal ilişkinin/dengenin doğru ve sağlam bir zemine oturtulmasıyla mümkün hale gelecektir. $\mathrm{Bu}$ da insanın, kendi fiilleri de dâhil olmak üzere din, kültür, tarih veya gelenek gibi maddî veya manevî hiçbir şey için bir araç değil, bizatihi kendinin bir amaç olduğunu kabul etmekle gerçeğe dönüşecektir.

Anahtar Kelimeler: Yabancılaşma, İnsan, Ontolojik Yabancılaşma, Aksiyolojik Yabancılaşma, İnsanın Özü, İnsanın Varoluşu

\section{Giriş}

Gerek felsefe gerekse dinlerde, insanî varlığın umumiyetle iki temel boyut üzerinden ele alındığ1 görülmektedir. Bunlardan biri, onun varoluşsal mahiyet veya hüviyetiyle ilgili ontolojik; diğeri ise, eylemselliğiyle ilgili aksiyolojik boyutu olarak kaşımıza çıkmaktadır. Burada meselenin ilk kısmında insanın öz, zat veya hakikati; diğerinde ise, buradan sadır olan iş, güç veya fiilleri söz konusudur. $\mathrm{Bu}$ nedenle insanın her iki boyutuna hâkim olan özellikleri dikkate alarak onu bir yönüyle "ontolojik bir mahiyet", diğer yönüyle ise "aksiyolojik bir kaynak/mihrak" olarak da nitelendirebiliriz.

Bu umumî durumdan sonra meselenin Kur'an'daki yansımasına bakacak olursak burada Allah'ın, insanı belirli bir ölçüye göre biçimlendirip, ruhundan üfledikten sonra onu varlığa getirdiği ifade edilmektedir. (32/Secde, 9; 15/Hicr, 29). Bu sebeple insanın varoluşu, Allah'ın varlık vermesi sebebiyledir. Öyleyse insanın hem "nefha-i ilahî" olarak nitelenen ruh veya manevi cevheri hem de bunu görünür kılan șeklî hüviyeti (Deniz, 2017: 77-79) Allah'ın eseridir. İnsanın kutsal bir varlık olması da buradan gelmektedir. Fârâbî bu durumu şöyle ifade eder:

"Sen iki tözden meydana gelirsin. Bunlardan biri biçim ve surete sahiptir, nitelik ve niceliği vardır, hareketli ve sakindir, yer kaplar ve bölünür. İkincisi ise, bu nitelikler bakımından birinciden ayrllır. Aklın kendisine ulaştığı, zihnin (vehm) ise uzaklaştı̆̆ özün gerçekliği konusunda birinciyle bir ortaklĭg yoktur. Sen hem yaratılmış âlemden hem de buyruk âleminden ögeleri bir araya toplamışsln. Çünkü senin ruhun Rabbinin buyruğundan, bedenin ise Rabbinin yaratmasindandır." (Fârâbî, 2003: 62; 1381: 121122). 
O halde, beşerî ve ilahî boyutuyla insan, Allah'nn eseri olarak dünyaya gelmektedir. Dünya âleminin ise, insanın varlık ve devamlılı̆̆ını mümkün kılacak şekilde tedbir edildiğini söyleyebiliriz. Zira Kur'an'da, bir yandan yeryüzünü imar, inşa ve ihya etmesi için insana gerekli güç veya yeteneğin verildiğinden (Hûd, 11/61) bir diğer yandan da yerde ve gökte ne varsa hepsinin yine insanın emrine musahhar kılındığından (Câsiye, 45/13) söz edilmektedir. Bu iki ayetin ortaya koyduğu müşterek manadan Allah'ın, insandan kendi gücünü kullanarak, emrine verilmiş olan varlığ 1 işleyip, değer veya değerler üretmesini murat ettiği neticesine ulaşabiliriz (Çetintaş, 2017: 163).

Kur'an'da yer alan bir başka ayette ise insanla, ağaç arasında metaforik bir ilişki kurularak ağacı; canlı hale getirip, ayakta tutan niteliklerin kökler ve dallar olduğuna vurgu yapılmaktadır. İlgili ayetin devamında da, bu niteliklerin olmadığı bir ağacın kupkuru bir yapıya dönüşeceği ifade edilmektedir. (14/İbrahim, 24-26). Bu örneğe bakarak, insanın da, insan olarak varlık ve devamlılığının ancak fiilleriyle mümkün hale gelebileceğini söyleyebiliriz. Zira insan, ancak yaptıkları veya eylemleriyle insandır. Burada ne tür bir fiil üretileceğiyle ilgili tahsis, tahdit veya tayin edici herhangi bir beyanın olmaması; etik, estetik, epistemolojik, teknik veya sanatsal olanı başta olmak üzere her türlü kültür ve medeniyet değerlerini içeren fiiller üretmemizin isteniyor olduğu sonucunu çıkarabiliriz ki bunu da, İslâm dininin kendi terminolojisi içerisinde "amel-i salih" olarak da nitelendirebiliriz (Hatiboğlu 2012: 158-159).

Öyleyse Müslüman'ın, kendini ayakta tutarak, onur ve vakarını muhafaza edecek fiil veya değerler üretmesi gerektiği, dinî bir öğüt veya tavsiye olarak değerlendirilmelidir. Dahası böylesi bir durum, meselenin dinî boyutunun yanı sıra dünyevî bir zorunluluk olarak da kendini hissettirmektedir. Çünkü insanoğlu, yaşamak için iş yapmak veya fiilde bulunmak durumundadır. Aksi takdirde insanın ontolojik mahiyetini muhafaza edecek bir dünya inşa etmesi ve hatta ahretini kazanması mümkün olmayacaktır. Bu nedenle, ister yeryüzünün imar ve inşası isterse ahiret yurdunu kazanmak için olsun insanın, kuvveden fiile geçerek kendisi için lazım gelen iş veya davranışları üretmesi bir zorunluluk arz etmektedir.

\section{Aksiyolojik Yabancılaşmanın Oluşumu}

İnsanın zatı ile ürettiği fiiller arasında kurulan ilişkinin keyfiyeti/mahiyeti ise büyük önem arz etmektedir. Çünkü insanın özsel olarak değersel konumu, bu ilişkinin kurulma şekline göre oluşmakta veya belirlenmektedir. Geleneksel İslâm düşüncesinde en azından teorik olarak insanın fiilleri, zatının bir izdüşümü olarak görülür. Tabiatıyla iyi kötü, güzel çirkin ya da doğru yanlış ayırımı yapmaksızın ifade edelim insanın ontolojik mahiyeti neyse, aksiyolojik görünürlülüğü de buna göre şekillenmektedir. Bu nedenle insanın zatî hüviyeti, fiillerinin renk ve şeklini de ortaya koymaktadır. Haliyle burada, insanın kendisi veya zatını temele alan bir tanımlama veya konumlandırma söz konusudur.

Fakat tarihsel süreç içerisinde bu tabii akışın hilafına insanın zatı karşısında, fiillerinin daha öne çıktığı/çıkarıldığı manzaralarla karşılaşmak da mümkün olabilmektedir. Bu tür durumlarda insanın kendinin geri planda kalarak, tanımlama veya belirleme üstünlüğünün zatî olandan fiilî alana geçtiği müşahede edilmektedir. Özgül ağırlığı veya merkezi konumu sarsılan insan böylece fiilleri karşısında zayıflayarak, mevzii kaybetmektedir. Haliyle burada insanın içinde bulunduğu eskiye dair zaman ve mekân algısı, yerini, yenisine bırakmaktadır. Zat ile fiiller arasındaki konumsal ilişkinin değişerek özgün, beşerî bütünlüğün bozulduğu bu yeni durumda ise insan, üretmiş olduğu kendi eylemlerinden soğuyarak, uzaklaşmakta ve bunlar üzerinden kendine yabancılaşmaktadır. ${ }^{1}$

\footnotetext{
${ }^{1}$ Umumi anlamıyla, Latince "alienatio" olarak ifade edilen yabancılaşma kavramı; "Bir şeyi başkasının yapmak, alıp götürmek, çıkarmak" gibi anlamlara gelen "alienare", bu da; "Başkasına ait veya başkasıyla ilgili olmak" anlamına gelen "alienus" kelimesinden gelmektedir. "Alienus" ise; sıfat olarak "başka", isim olarak ise "başkası" anlamına gelen "alius" kökünden türetilmiştir. ${ }^{1}$ Bu anlamda tarihsel izdüşümlerini de dikkate alarak yabancılaşma kavramını; bilinen, tanıdık,
} 
Buna göre felsefenin terminolojisi içerisinde yabancılaşmay1; insan ile onun tarihsel var oluşu arasında ortaya çıkan çelişki veya sapmalar olarak nitelendirebiliriz. Zira türsel bir varlık olarak insanın sahip olduğu güç, imkân veya nitelikleri, onun şahsi mülkiyeti sayılır. Bu nedenle, öz ile varoluş arasında ortaya çıkan bu çelişki veya sapmalar insanla, sahip olduğu nitelik veya özellikler arasındaki sahiplik ilişkisinin kopması veya bozulması anlamına gelmektedir. Çünkü burada insanın güç, imkân veya enerjisi, kendi dışında başka bir alana akmakta, bu da, insanın dışsallaşması anlamına gelmektedir ki bu durum, onun ortak varoluşla olan birliğini bozmakta veya tümüyle yok etmektedir (Ertoy, 2007: 20).

Zaman, mekân veya kültür ayırımı yapmaksızın ifade edelim, tarihin akışı içerisinde ortaya çıkan aksiyolojik yabancılaşma, dahası bu durumun yol açtığı büyük düşüşlerin temelinde, insanın varoluşsal birliğinin bozularak, fiiller karşısında özün geri planda kalması yatmaktadır. Zira burada insan, zatından ziyade üretmiş olduğu fiillerin hatırına göre muamele görmektedir. Veya önemli olan, insanın kendisi değil de, üretmiş olduğu fiillerin dış dünyadaki karşıllı̆̆ıdır. Haliyle bu durum, insanın gaye varlık ${ }^{2}$ olma konumunu yitirip, başkası veya başka şeyler için araçsallaşmasına yol açmaktadır. Çünkü bu tabloda makbul veya muteber insan olmanın ölçü veya miyarı, üretilen fiillerin dış dünyanın ihtiyaç veya gereksinimlerini karşılama, doyurma veya tatmin etme gücüne göre oluşmaktadır. Böylece insanın özgül ağırlı̆̆ı, içeriden dışarıya yahut özden forma kaymaktadır. Bu aşamadan sonra insana dair tanımlama, değerlendirme veya konumlandırmalar, onun özü veya ontolojik mahiyetinden ziyade, aksiyolojik görünürlülüğü üzerinden yapılmaktadır.

Böylece önem veya öncelik bakımından insanın özü veya zatıyla, fiilleri arasındaki konumsal ilişki bozulmakta ve insani varlık, kendi eliyle ürettiği şeyler üzerinden kendine yabancılaşmakta veya yabancılaştırılmaktadır. Çünkü insan, emek harcayarak oluşturduğu özünü, yapmış olduğu iş, güç veya fiillere aktarmakta, bu fiiller ise dışsallaşarak nesneleştikten sonra diğer insanlar tarafından bir eşya veya meta gibi kullanılmaktadır. Zatı ile onun izdüşümü olan fiilleri arasındaki müşterek varoluş dengesi bozulan insan böylece, kendi kendine yabancılaşmaktadır. Bu duruma düşen insan üretkenliği ve vakarının yanı sıra, kendini ayakta tutan moral ve motivasyonunu da kaybetmektedir (Seeman, 1959: 784-789).

\section{Aksiyolojik Yabancılaşmanın Muhtelif Formları}

Dinden ahlaka, sanattan bilime, ekonominden kültüre kadar insanın, merkezinde yer aldığ bütün fiiller yabancılaşma sürecinin bir parçası haline gelebilmektedir. Daha açık bir ifadeyle insan, bütün bu alanlar üzerinden yabancılaşmaya maruz kalabilmektedir. Bunun tarihi, karakteristik örneklerinden birisi, Aydınlanmayı müteakip Sanayi Devrimiyle birlikte Batı dünyasında ortaya çıkan yeni ekonomik düzenin işçi sınıfını maruz bıraktığı fiiller üzerinde kendini dışa vuracaktır. Veya insanlığın başından bu yana daima var olan böyle bir problem bu dönemlerde, Hegel ve Feurbach'ın ortaya koyduğu benzer çabaları müteakip Marx'ın, işçi sınıfının, ürettikleri üzerinden kendi kendine nasıl yabancılaştığını gösteren çalışmalarıyla gündeme

aşina olduğumuz bir durumdan bilinmeyen, tanınmayan başka bir duruma geçiş olarak nitelendirebiliriz. Öyleyse yabancılaşma, zihinsel ve ruhsal bir değişim veya dönüşümü ifade etmektedir. Tabiatıyla burada alışı olduğumuz mevcut veya eskiye dair zaman ve mekan, yenileriyle yer değiştirmektedir. Bu anlamda yabancilaşma bir boyutuyla; insan ilişkilerinin ve eylemlerinin kendisinin kontrolü dışındaki şeylerin nitelikleri veya eylemlerine aktarılıp, bunlar tarafından yönetilir hale gelmesi/getirilmesi, bir diğer boyutuyla ise; insanın kendi kendine yabancılaşması veya kendini, kendine yabancılaştırması gibi anlamlara gelmektedir. (Schact, 1970: 10; Schmitt, 2003: 1-2: Wood, 2005: 12; McQuail, 2009: 33; Petrović, 2006: I/120).

${ }^{2}$ Fârâbî'ye göre mümkün varlıklar âleminde niteliğe dayalı belirli mertebeler oluşmaktadır ki burada, aşağıda bulunan her bir varlık yukarıdakinin hizmetindedir. Hava, su, toprak ve ateşten oluşan dört unsur, bir üst kategoride bulunan madenlere, onlar da daha üstüne hizmet etmektedir. Canlılar içerisinde ise bitkiler hayvanlara, onlar da insana hizmet etmektedir. İnsan ise mümkünler âleminde kendisinden üstün başka bir varlık cinsi bulunmadığı için hiçbir şeye karşı hiçbir surette herhangi bir sorumluluk içerisinde değildir. Zira insanî nefsin, bitkisel ve hayvanî nefse göre akıl, irade ve hatta vicdan bakımından üstünlüğ̈ söz konusudur. Öyleyse varlık içerisindeki bu ayrıcalıklı konumuyla insan, mümkün varlıklar âlemindeki diğer varlıklar gibi bir vasıta veya araç değil, bizatihi kendisi amaç varlıktır. (Fârâbî, 2012: 73) 
gelecektir. Bu anlamda bir malın üretimi; aktarılan insan emeğinin maddileşerek, dışsallaşmasına, bu da, özün yabancılaşarak, değersizleşmesine yol açmaktadır. Çünkü bu sürecin sonunda emeğin ürettiği nesne, yani emeğin ürünü, emeğin karşısına yabancı bir şey, kendini üretenden bağımsız bir güç olarak çıkmaktadır. Burada emek, bir nesneye aktarılarak, maddeleşmiş emek haline gelmektedir. Bir başka ifadeyle emek, nesneleşmektedir. Meseleyi tersinden alacak olursak, böyle bir nesneleşmeyle birlikte, emeğin gerçeklik kazanması, işçideki gerçekliğin yok olması anlamına gelmektedir. Böylece işçi, kendi emeğinin ürünüyle, yabancı bir şey veya nesneyle ilişki kurarmış gibi bir hissiyata kapılmaktadır (Marx, 2013: 75).

Haliyle burada işçi kendisini ne kadar harcarsa, karşısında yarattığı yabancı veya nesnel dünya da o derece güçlenmektedir. Böylece işçi, hayatını nesneye koymakta, ancak bu hayat, kendine değil, nesneye ait olmaktadır. Emeğinin ürünü, kendisi değildir. Onun için bu ürün ne kadar büyükse, kendisi o kadar küçülmektedir. Ürünün, işçiden dışlaştırılması; emeğinin sadece bir nesne, dışsal bir varoluş olduğu anlamına gelmemekte, aynı zamanda onun dışında bağımsız, ondan başka bir şey olarak var olduğu, karşısına dikilen bağımsız bir güç olduğu anlamına gelir. İnsanın kendi eliyle kendi düşmanını üretircesine, işçinin nesneye aktardığı hayat, yabancı ve düşman bir şey olarak kendi karşısına çıkmaktadır (Marx, 2013: 75-76).

Böyle bir durum ise insanın kendini, kendi evinde yabancı gibi hissetmesine yol açmaktadır (Swain, 2013: 10). Çünkü insan çalışıp, emek harcayarak pek çok ürün ortaya koymakta, ancak özünü vererek ürettiği bu ürün, kendi karşısına düşman olarak çıkmakta veya başkaları tarafından sahiplenilmektedir. Bir bakıma herhangi bir annenin, dünyaya getirip, emek harcayarak büyüttüğü çocuğunun kendine düşman hale gelmesi veya elinden koparılıp alınması gibi, insanın özü veya emeği de, ya kişiye hasım hale gelmekte veya başkaları tarafından sahiplenilmektedir. Zira burada insan veya onun gereksinimlerinden ziyade üretim, elde edilecek kâr veya dış dünyanın ihtiyaçları ağır basmaktadır (Swain, 2013: 58). Üstelik insanın ürettiği bu emeğin çarşı, pazarda alınıp, satılan maddi bir meta haline gelmesi, bu bütünlüğü tümüyle bozarak, insan ile fiilleri arasındaki mesafeyi iyice açmaktadır (Marshall, 1999: 798-799).

Böylece üreten ile ürün veya fail ile fiil arasındaki varoluşsal ilişsi kopararak, ayrışmaktadır (Tally, 2009: 2) Bu kopma durumu, insan ve insanın yaşam etkinliği arasındaki ilişkinin tümüyle kesildiği anlamına gelmekte olup bu aşamadan sonra insanın kendi davranışlarını yönlendirme veya yönetme iradesi de ortadan kalkmaktadır (Ollmen, 2015: 217).

Aksiyolojik yabancılaşma olgusu, ekonomik veya maddî işlerin yanı sıra din, ahlak, sanat, felsefe ya da kültür gibi manevî yönü ağır basan alanlarda da müşahede edilebilmektedir. Tarihin geniş dönemleri insanların inanç, ahlak veya sanatsal iş ve uğraşlarla inşa ettikleri manevi değerler üzerinden kendi kendilerine nasıl yabancılaştıkları veya yabancılaştırıldıklarını gösteren örneklerle doludur. Bu anlamda örneğin herhangi bir sanat dalıyla ilgili olarak sanatkâr, özünü aktararak, bir sanat eseri ortaya koyar ki bu; onun aklî, hissî veya muhayyile gücünün bir yansıması veya izdüşümü olarak ortaya çıkacaktır. Haliyle estetik bir ürün olarak ortaya çıkan bu eserle, sanatkâr özdeş hale gelecektir. Fakat bu aynı eser, başka insanların his, arzu veya isteklerini tatmin etmek üzere sahiplenilmekte ve sanatkârın özünü aktararak ortaya koyduğu imge, düş veya hayalleri, diğer insanların estetik duygularını besleyen birer vasıtaya dönüşmektedir. İşte, insanların his veya duygu dünyalarının birer tatmin aracı olarak dolaşıp duran, somut hakikatler üzerindeki bu düş veya hayaller, sanatkârın, kendinden uzaklaşan öz benliğinden başka bir şey değildir.

$\mathrm{Bu}$ aşamadan sonra sanatkâr; insan olduğundan daha çok, üretmiş olduğu eserlerin, daha doğrusu, bu eserlerdeki estetik cazibe veya çekiciliğin, diğer insanların his, duygu veya arzuları üzerindeki etkisinin hatırı için itibar görmektedir. Bir önceki verdiğimiz örnekte, diğer insanlar üzerine yönelik maddî veya bedensel bir fayda söz konusuydu. Burada ise manevî veya ruhsal bir fayda veya tatmin söz konusu olmaktadır. Ancak her ikisinde de işin özü değişmemekte ve insanın ontolojik değeri, aksiyolojik boyutunun gölgesinde veya gerisinde kalmaktadır. 
Sanatla ilgili bu durumun bir benzeri ahlakî alanda da müşahede edilebilmektedir. Burada ise örneğin inanç sahibi bir insan ya da daha özel anlamda herhangi bir Müslüman, Allah'ın hoşnutluğu veya rızasını kazanmak maksadıyla, nefsanî zorlukların üstesinden gelerek hal, hareket veya davranışlarını düzene koyar. Bunu, İslâm'nn kendi terminolojisi içerisinde "ahlâk1 güzelleştirmek" ya da "Allah'ın ahlakıyla ahlâklanmak" gibi nitelemelerle de ifade edebiliriz ki bu durum, umumiyetle kendini; yumuşak/güzel söz veya güzel davranışlar olarak dişa vurmaktadır. Haliyle bu davranış şekli, Hacı Bayram-1 Veli'nin "İnsan, zatını, fiillerinde seyreder." dediği gibi, insanın ahlâki özü veya zatının bir yansıması olarak ortaya çıkacaktır (Akseki, 2016).

Ancak insanın inanç, duygu, düşünce veya irade gibi özsel nitelikleriyle inşa ettiği bu güzel ahlâk, zaman zaman fena niyetli insanların istismarına maruz kalabilmektedir. Böylesi insanlar, ahlak sahibini sorgusuz, sualsiz kör bir itaate razı edebilmek için, onun sahip olduğu maneviyatı da kolaylıkla araçsallaştırabilmektedir. Bu tür yönlendirmelere rıza göstermeyle, Allah'a rıza göstermeyi özdeş kabul eden ahlak sahibi ise, iyilik ve ihsan umuduyla, özünü vererek inşa etmiş olduğu fiillerinin doğruluk/hakikat değerinin ölçüsünü istismarcının iradesinde aramakta veya ona bağlamaktadır. Bu andan itibaren karşı tarafın ortaya koyduğu her bir fiil, ahlak sahibinin fiilleri için de kesin bir ölçü haline gelmektedir. Çünkü o, davranışlarını; kendi öz veya gerçekliğini dikkate alarak değil, içsel olarak bağlanmış olduğu kişinin istek ve arzularına göre uyarlamaktadır. Böylece ortaya konulan fiillerin şeklî hüviyeti ahlak sahibine, özsel iradi mahiyeti ise karşı tarafa ait olmaktadır. Ahlakî fiiller üzerinden başkasının iradesine teslim olarak, körü körüne onun peşinde sürüklenen işte bu insan, özüne yabancılaşmış bir öteki veya özünü kaybetmiş bir yabancı olarak karşımıza çıkmaktadır.

Burada ekonomik, sanatsal veya ahlâki alana münhasır fiiller üzerinden ele aldığımız aksiyolojik yabancilaşma olgusunu, insandan doğan bütün fiillere teşmil edebiliriz. Bu nedenle insanın üretmiş olduğu her bir fiil, onun yabancılaşmasına yol açabilmektedir. Bu süreçte fiillerin renk ve mahiyeti değişse de, insanın, özünü aktararak üretmiş olduğu bu fiiller üzerinden maruz kaldığı yabancılaşma olgusu, bir yasa gibi kendini daima muhafaza etmektedir. Dahası, yabancılaşmanın da ötesinde insan, bu fiiller yoluyla kendi kendine hasım hale gelebilmektedir. Çünkü insan burada bir yönüyle ötekileşmiş kendisiyle mücadele etmek durumunda kalmaktadır. Zira ortaya konulan bu fiiller nesneleştikten sonra, kendi gerçekliğini üreterek, asıl sahibinin karşısında kendi paradigmasını oluşturmakta ve bunun üzerinden doğduğu ana yapıyı biteviye yıpratmaktadır. Çünkü bu tür fiiller dışsallaşıp, dolaşıma girdikten sonra, sahibinin bunlar üzerindeki kontrol veya denetimi ortadan kalktığ 1 için, bu fiillerin ürettiği zarar sahibine dönerken, faydası ise kullanıcının hanesine akmaktadır. Bu nedenle yabancılaşma olgusu, insanın, kendi eliyle sürekli olarak kendine zarar veren bir düşman üretmesi anlamına da gelmektedir.

\section{Sonuç}

Aksiyolojik yabancılaşma, öz ile fiiller bağlamında insanın var oluşsal bütünlüğünün bozulmasıyla birlikte başlamakta, fiilleri karşısında insanın özgül ağırlı̆̆ının öneminin zayıflaması veya tümüyle kaybolmasıyla birlikte somut bir gerçekliğe dönüşmektedir. Haliyle bu durum, insanın, varlık içerisindeki konumuyla birlikte, insan olma onur ve vakarına da aynıyla yansımaktadır. Zira bu durumda insan, bizatihi bir değer varlığı olmaktan çıkıp, nesneleştirmekte veya şeysel varlık haline dönüşmektedir. Halbuki insan, kendisi dışındaki hiçbir şey için bir araç değil, bizatihi amaç varlıktır. İnsanın sahip olduğu yücelik de, gücünü buradan almaktadır. Ancak yabancılaşma olgusu bunu ortadan kaldırmaktadır.

Yanı sıra, yabancılaşmanın ontolojik boyutunda insan, doğrudan öz, mahiyet veya zatı üzerinden yabancılaşmaya maruz kalmakta, bunda da daha ziyade kendi iç hakikatleri rol oynamaktadır. Meselenin aksiyolojik boyutuna gelince burada ise, fiiller üzerinden, dolaylı bir yabancılaşma söz konusu olup bunu, insanın iç dinamiklerinden daha çok, dış gerçekliklerin belirlediği anlaşılmaktadır. Haliyle bu sorunu da, insanın iç dünyasıyla birlikte muhtemelen ondan daha çok, buna yol açan dış koşulları dikkate alarak çözüme kavuşturmamız gerekmektedir. 
Kültürlerin kendine özgü karakteri, bu karakterin ürettiği siyaset tarzı ya da bu alanların insanı ele alış biçimi gibi hususları, bu dış koşullar arasında sayabiliriz.

Ayrıca insanın davranışlarına hâkim olan bilinç, dış dünyanın davranış kod veya kalıplarıyla oluştuğu için, yabancının bilinci de, asli/içsel bir bilinç değil, ferî/dışsal bir bilinç olacaktır. Davranışlarda başlayıp, oradan zihin ve ruha sirayet eden bu yeni durum karşısında yabanc1, tümüyle dönüşmüş bir yap1 olarak ortaya çıkmaktadır. Bu nedenle aksiyolojik yabancılaşmayla birlikte insan, kendisine verilmiş olan ilâhî tabii dokusunu kaybederek, tümüyle başka bir insan haline gelebilmektedir. Haliyle buradan sadır olan iş, güç veya fiillerin de şeklî hüviyeti yabancıya; özsel iradî mahiyeti ise başkalarına ait olacaktır.

Aksiyolojik yabancılaşma, insanın bütün fiillerine musallat olabilmektedir. Yani insan, üretmiş olduğu her bir fiil üzerinden yabancılaşmaya maruz kalabilmektedir. Bu bakımdan fiillerin şekil, renk veya mahiyeti değişse de, bu fiiller üzerinden ortaya çıkan yabancılaşma olgusu, bir kanun gibi kendini daima muhafaza etmekte ve daima yabancılaşmaya teşne fiillere ilişerek, hükmünü icra etmektedir.

Son olarak insanı yabancılaşmaya maruz bırakan fiiller, bunun da ötesine geçip ona hasım hale gelebilmektedir. Zira emek harcanarak ortaya konulan bu fiiller, nesneleştikten sonra, diş dünyanın zihinsel ve ruhsal verileriyle kendi gerçekliğini üreterek, sahibinin karşısında kendi paradigmasını oluşturmakta ve bunun üzerinden ister istemez doğduğu yap1 hedef haline gelmektedir. Çünkü insan burada bir yönüyle ötekileşmiş kendisiyle mücadele etmek durumunda kalmaktadır. Haliyle bu tür fiiller dışsallaşıp, dolaşıma girdikten sonra, sahibinin bunlar üzerindeki kontrol veya denetimi ortadan kalktığı için, bu fiillerin ürettiği zarar sahibine dönerken, faydası ise kullanıcının hanesine yazılmaktadır. Bu nedenle aksiyolojik yabancılaşma aynı zamanda insanın, kendi eliyle kendine zarar veren bir düşman üretmesi anlamına gelmektedir.

Öyleyse bu tür tahrip edici problemlere maruz kalmamak için insan ile onun tarihsel var oluşu arasındaki bütünlüğün bozulmaması gerekmektedir. Bu ise zat ile fiiller arasındaki konumsal ilişkinin/dengenin doğru bir zemine oturtulmasıyla mümkün hale gelecektir. Buradaki doğru zemin ise, bizatihi bir değer varlığı olarak insanın, kendi fiilleri de dâhil olmak üzere maddî veya manevî hiçbir şey uğruna feda edilmeden, varlık içerisindeki gayesel konumunun muhafazasıdır.

\section{Kaynakça}

Akseki, A. H. (2016). Ahlâk Dersleri Ahlâk İlmi ve İslâm Ahlâk, sad.: Ali Aslan Aydın, Yasin Yayınevi.

Çetintaş, İ. (2017). "Aksiyolojik Gelişim Sürecinin Dini Pratikteki İzdüşümü", İslâmî Araştırmalar, 28(2), 161-167.

Çetintaş, İ. (2014). İslam Düşüncesinde Değerler Metafiziği, Elis Yayınları.

Ertoy, M. (2007). Yabancılaşma, Lotus Yayınları.

Fârâbî, (2003). "Felsefenin Temel Önermeleri” (Kitabu'l-Fusûs fi'l-Hikme), çev.: Mehmet Dağ, OMÜ İlâhîyat Fak. Dergisi, s. 14-15, 50-73.

Fârâbî, (1381). Fususü'l-Hikme ve Şerhuhû, şerh: İsmail Hüseyni Şeneb Gazani, tahkîk: Ali Ücibi.

Fârâbî, (2012). es-Siyasetü'l-Medeniyye, çev.: M. Aydın, A. Şener, M. R. Ayas, Büyüyen Yayınları.

Hatiboğlu, M. S. (2012). İslam'in Aktüel Değeri Üzerine 1, Otto Yayınları.

Marx, K. (2013). 1844 El Yazmaları, çev.: Murat Belge, Birikim Yayınları. 
Marshall, G. (1999). Sosyoloji Sözlüğü, çev.: Osman Akınhay, Derya Kömürcü, Bilim ve Sanat Yayınları.

McQuail, J. A. (2009). “Alienation in Aldous Huxley's Brave New World”, Bloom's Literary Themes: Alienation, Edit.: Harold Bloom.

Ollman, B. (2015). Yabancılaşma Marx’ın Kapitalist Toplumdaki İnsan Anlayışı, çev.: Ayşegül Kars, Yordam Kitap.

Petrović, G. (2006). "Alienation". Encyclopedia of Philosopy. ed. Donald M. Borchert vd., Cilt. 9, ss. 120-127. USA: Macmillan Reference.

Schact, R. (1970). Alienation. New York: Doubleday \& Company,

Schmitt, R. (2003). Alienation and Freedom. Colorado: Westviev Press.

Seeman, M. (1959). "On the meaning of alienation". American Sociological Association 24 (6), 783-791.

Swain, D. (2013). Yabancılaşma, çev.: Hande T. Urbarlı, Uluslararası Akım Tanıtım Yayınları.

Tally, R. T. (2009). "Reading the Original: Alienation, Writing, and Labor in 'Bartleby, the Scrivener' ", Bloom's Literary Themes: Alienation, Edit.: Harold Bloom.

Wood, A. W. (2005). "Alienation". the shorter routledge encyclopedia of Philosophy. ed. Edward Craig. Taylor \& Francis Group 